\title{
The Impact of the Balanced Scorecard on Corporate Performance: The Case of an Australian Public Sector Enterprise
}

\author{
Ridwan Ridwan ${ }^{1}$, Harun Harun ${ }^{2}, \mathrm{Yi}_{\mathrm{An}}{ }^{3} \&$ Imam Mujahidin Fahmid $^{4}$ \\ ${ }^{1}$ Faculty of Economics, Tadulako University, Indonesia \\ ${ }^{2}$ Faculty of Business, Government and Law, The University of Canberra, Australia \\ ${ }^{3}$ Waikato Management School, The University of Waikato, New Zealand \\ ${ }^{4}$ Faculty of Agriculture, Hasanuddin University, Indonesia \\ Correspondence: Harun Harun, 13/5 Totterdell Street Unit 13, Belconnen, ACT, 2617, Australia. Tel: \\ 61-02-6201-5960. E-mail: harunak2001@yahoo.com
}

Received: November 23, 2012

Accepted: July 22, 2013

Online Published: September 23, 2013

doi:10.5539/ibr.v6n10p103

URL: http://dx.doi.org/10.5539/ibr.v6n10p103

\begin{abstract}
The aim of this study is to examine the impact of a corporate scorecard system inspired by the Balanced Scorecard (BSC) adopted in a public sector commercial entity in Australia. Based upon a case study on the Freemantle Port Authority, Western Australia this paper shows that although the policy to adopt the scorecard was legally imposed from outside, it has significant impacts on the organizational structure, operation as well as the overall performance of the organization. A main contribution of this paper is that it demonstrates that a coherent link between the polices and rules imposed from outside and strategies and performance measurement systems developed and used inside organization is a key factor in achieving expected outcomes of new managerial innovation practices.
\end{abstract}

Keywords: the balance scorecard (BSC), key performance measurement systems, the public sector

\section{Introduction}

In the last two decades, conventional performance measurement systems have been seen as inadequate and insufficient for appropriately and pertinently measuring firm's performance in the current environment. Quoting Kaplan and Norton (1996), Hemming (2012) exemplifies that as companies around the world transform themselves for competition based on information, their ability to exploit intangible assets has become far more decisive than their ability to invest in and manage physical assets. This trend shows that the development and the adoption of more sophisticated managerial innovation system such as the balanced scorecard (BSC) used in planning, measuring and monitoring firm's performances are increasingly popular. In recent years, the use of the BSC and its variations not only applies to privately owned commercial entities, but also to the public sector and non-commercial entities (Lawson, Stration, \& Hatch, 2006; Kaplan, 2010). It is reported that more than 50\% of the Fortune 500 companies adopt the BSC or its variations as a main performance measurement and strategic management tool (Gumbus, 2005).

The aim for adopting the BSC or its variations is to capture data on what has happened and to measure the factors that drive profitable growth. As stated by Hurd (1998) that for high technology firms where everything changes so quickly, performance measurement systems need to be forward looking so as to avoid being in a situation where it's too late to respond. Beyond this, the use of such innovations is not only driven by economic reasons, but also it is also seen as a response to normative pressure on better governance. Apart from corporate scandals, there has been normative pressure for better governance (for corporations) as the business environment has become more volatile, less predictable, more globalized (Ratnatunga \& Alam, 2012, p. 343). Therefore the adoption of a key performance indicators (KPIs) system, for example, should be developed as an integral part of BSC adoption, as it provides the basis on which the system is part of the critical linkage between strategy execution and strategy adjustment (Slater, Olson, \& Reddy, 1997). It is through measurement that corrective measures can be taken to ensure performance. And because the performance of the firm is a comprehensive result, its measurement and evaluation system should be equally comprehensive and multidimensional to achieve alignment and coherence with the notion of its performance (Moore \& Lyon, 1995). 
However Robinson (2002), Braam and Nijssen (2004) remind that previous studies have mixed evidence regarding the impact of a corporate scorecard on performances on corporate defined objectives. Moreover, in the public sector context there is fairly broad consensus that there are significant challenges in transposing the BSC principles to public sector organizations, and that particular circumstances unique to the public sector give rise to the need for adjustments in both BSC design and implementation and it should be implemented (Gadanne \& Sharma, 2009, p. 2). Similar comments were also recently emphasized by Kaplan (2001), Niven (2002); Wisniewski and Stewart (2004), Adcroft and Willis (2005) and Greatbanks and Tapp (2007). Drawn from these perspectives, it is therefore vitally important for the policy makers and managements of public sector organizations to take into account the environments and strategic factors in developing and implementing any managerial innovations tools such the BSC or its variations.

The aim of the study is to examine the impact of the use of a corporate scorecard system adapted from the BSC on the performances of a state-owned company. The site of this study is the Fremantle Port Authority (referred to as FPA), a Western Australian government-owned company. By using a case study, document examination was carried out to understand the context and implication of the use of corporate scorecard in the firm organization structure, key performance indicators and its defined goals achieved. The rest of this paper is outlined as follows: literature review; research site, methods and scope of the study; findings and discussion; and conclusion and of the study.

\section{Literature Review}

Since the 1980s the efforts to transform public sector organizations into new public management (NPM) practices have been prevalent in Australia, New Zealand and the UK (Christensen \& Parker, 2010; Pollanen \& Loiselle-Lappointe, 2012). It is argued that such reforms were carried out to response greater pressure from tax payers and other strategic stakeholders to show performance improvements (McAdam, Hazlett, \& Casey, 2005) and better accountability (Barry 2000; Norcott, Llewellyn, \& Kober 2009). In recent years such reforms were also undertaken in European, Asian and African countries and other part of the world (Harun \& Kamase, 2012).

Under the NPM doctrines it is believed that the use of accounting or performance management system drawn from commercial practices could improve the decision making process, performance measurement system, and better financial and non financial indicators for the public sector (Northcott et al., 2009; 2005; Malina, Nørreklit, \& Selto, 2007). In recent years a number of business-style accounting and managerial systems such accrual accounting, performance-based budgeting and also the BSC have been mobilized and implemented. Such a trend not only applies to governmental organizations (departments and agencies) but also for state-owned enterprises (Jacobs, 2008).

However, as earlier indicated, prior studies still debated how the implementation of the BSC lead to expected outcomes (Johanson, Skoog, Backlund, \& Almqvist, 2006). Accounting scholars also point out issues as to the BSC's effectiveness and the lack of clear cause-and-effect relationships, lack of clarity, and failure to consider some types of stakeholders (Maltz, Shenhar, \& Reilly, 2003; Johanson et al., 2006). As argued by Nørreklit (2003) and Malina et al. (2007) that from a philosophy of science perspective that Kaplan and Norton have confused causal and logical relationships (Norcott et al., 2009). An earlier concern on this was raised by Otley's (1999) that BSC causal chain is "very much a simplification of reality" (Northcott et al., 2009, p. 5).

It is also important to note that in contrast to the results of these studies, recent trend show the ABC is still one of the most popular managerial tools adopted by companies around the globe (Northcott et al., 2009). Therefore further studies should investigate how implementation of the BSC affects the managerial practices and performances from a practical level as suggested by Hoque and James (2000) and Malina et al. (2007). These studies are not only relevant for enriching the literature on performance measurement systems but also for policy and decision making in organizations across sectors (Kaplan, 2001; Johanson et al., 2006).

\section{Research Site, Methods and Scope}

The site of this study is the Freemantle Port Authority in Western Australia (FPA). FPA is a principal general cargo port for Western Australia. It is situated on the west coast-around twenty kilometers from Perth Central Business District. The Inner Harbor, which opened in 1897, is located at the mouth of the Swan River adjacent to the City of Fremantle. The Outer Harbor that is twenty kilometers further south of at Kwinana-Coockburn Sound was opened in 1955. The FPA is responsible for an area of land and water covering 383 square kilometers (FPA, 2001; 2011).

FPA is a Western Australia's largest cargo port and one of the fastest growing general cargo-ports in Australia. FPA, a Western Australian Government owned enterprise, is the strategic port manager with the responsibility of 
ensuring that port services and facilities are provided in a reliable, competitive, and efficient manner (FPA, 2001). According to an economic impact study when this study was conducted, the port has made a major contribution to the Western Australian economy. The reports reveals that port activities generate annual revenue of \$A728 million and account for 5,792 full time jobs equivalent, including direct and flow-on effects. This figure represents $0.8 \%$ of the state employments. These estimates do not include the total economic benefits of exports and imports other industries in the port area not directly involved with the transpiration of cargo (FPA, 2004). In a recent report the company has experienced a remarkable period of rapid growth in recent years. In 2011 the trade growth through the Port is indicated by a significant shift in financial performance, both in terms of profit and return on assets. In 2011-12 profit increased by 64.3 per cent to $\$ 19.364$ million and Return on Assets increased from 4.8 per cent to 7.2 per cent (FPA, 2011, p. 6).

Once FAP was transformed to become a commercial entity in 1996, the port is a mixture of both FPA and private owned facilities and services. Services provided directly by FPA include ship scheduling and berthing allocations, port communications, safety, emergency response, hazardous cargo services, and quarantine and waste disposal services (FPA, 2001; 2012). FPA also cooperates with Pilotage Company, as a commercial entity contracted by FPA in providing its services. Services provided directly by the private company include stevedoring, towage, line boats, bankers and ships' providers. In addition, FPA also cooperates with Commonwealth Government agencies responsible for customs, quarantine, and maritime safety activities (FPA, 2001; 2011).

Drawn from a case study, this investigation primarily relies on document examination of official reports issued by FPA. In this case, we reviewed background information regarding the company since 1990 and the development, implementation and impact of a scorecard system since it was adopted in 1999 until 2001. Through this review we analyzed official documents including annual reports (CEO's reports, financial statements) and other related publications as a means to compare and understand the differences of FPA's performances before and after the implementation of the company's corporate scorecard. In support, we also reviewed and examined related documents related to the company's performances issued by other parties. Therefore this study was not only primary based on the document issued by the company but also from other sources to better understand the context, history and the impact of corporate scorecard use in a public sector context.

\section{Findings and Discussion}

This section discusses two main issues: (1) the implementation of Act 1999 and the development of corporate scorecard at FPA, and (2) the impacts of the corporate scorecard on the organization structure, key performance indicators (KPIs) developed, and performances achieved by FPA.

\subsection{Implementation of Act 1999 and Corporate Scorecard of FPA}

Rapid technological innovation and an evolving business environment, together with long-term changes in customer needs, were seen as the main reasons why FPA replaced the Act 1902 and the Act 1993 with the Act 1999. Through the new Act, the idea to modernize FPA was realized when it became a commercial entity in 1996. Therefore the Act can be seen as a corner stone for FPA to empower its willingness to modernize all aspects of operations and to provide a clear trade facilitation role for the corporate with a commercial focus.

Thus it can be seen that the Act 1999 was the driving force for the company to develop a corporate scorecard, as a strategic tool designed to assist FPA to monitor its overall business progress, and the extent to which the corporation operation has met its successful critical targets in key areas (see Table 1). As the company reports, the corporate scorecard has helped FPA in providing a monthly basis report to every staff of all levels with regular reports being given to staff. Along with the use of the corporate scorecard as a management tool used in reporting both the financial results and the measurement of tasks have been improved; FPA also continues to use a managerial tool called "Integrated Management System Framework" as one type of information used by the company to identify opportunities for improvements. The framework is seen as one of industry best practices in Australia (FPA, 2001). And the Integrated Management System Framework was also a crucial part of the information provided in the company's new scorecard. As such with the support of the scorecard drawn from the BSC, the FPA has been regularly supplied with updated information on monthly basis on wide range of areas, including the company's Leadership System, Values, Communications, Stakeholder and Community Liaison, Strategic Planning, Corporate Performance Reporting, Monitoring the External Environment, Management and Improvement of Process, Innovation, Supplier and Contractor Relationship (FPA, 2001; 2012). 
Table 1. Fremantle port authority corporate scorecard

\begin{tabular}{|c|c|c|}
\hline Perspectives & Critical Success Factors & Measures \\
\hline \multirow[t]{5}{*}{ Business results } & \multirow[t]{5}{*}{ Business success and sustainability } & Financial results \\
\hline & & Trade results: \\
\hline & & Total trade \\
\hline & & Containers \\
\hline & & Action on complains \\
\hline \multirow[t]{3}{*}{ Services and facilities } & \multirow[t]{3}{*}{ Reliable and cost effective } & FPA real price index \\
\hline & & Total port charges per ship visit \\
\hline & & Ship delay time \\
\hline \multirow[t]{2}{*}{ Trade development } & \multirow{2}{*}{$\begin{array}{l}\text { Meet customers' expectation and help their business to } \\
\text { grow }\end{array}$} & Survey on customers satisfaction \\
\hline & & Customer feedback on priority issues addressed \\
\hline \multirow[t]{6}{*}{ Business environment } & \multirow{3}{*}{$\begin{array}{l}\text { Best practice system through innovation and } \\
\text { improvement }\end{array}$} & Overall risk profile \\
\hline & & ABEF guide self assessment \\
\hline & & External audits on environmental management system \\
\hline & \multirow[t]{2}{*}{ Committed, empowered and knowledgeable staff } & Lots time injured \\
\hline & & Staff satisfaction monitored \\
\hline & Community / stakeholder support & Community support index \\
\hline
\end{tabular}

Source: Fremantle Port Authority Annual Report (2002).

\subsection{The Impact of Corporate Scorecard at FPA}

Following the corporate scorecard based on the Act 1999 introduced; changes have taken place in the company both in managerial organization structure and performances of FPA as discussed in the following sections.

\subsubsection{Corporate Structure}

Under the new Act, the Port Authority is established as a commercial entity and is governed by the Board of Directors. And the Board appointed by the Minister of Transportation. Before the implementation of the new Act, FPA corporate structure was led by a general manager and Chief Executive Officers (GM \& CEO) who ran and coordinated five main divisions of the port. The divisions are commercial and development units, accounting management unit, harbor maters and shipping services unit, human resources and internal audit units. A manager leads each unit of the divisions. The GM \& CEO was responsible to the Board of Commissioners. The Board is required to submit the annual report of FPA to the parliament annually.

Once FPA became a commercial entity in 1996, the corporation managerial structure was restructured. Under the new Act, the Chief Executive Officer (CEO) replaced the GM \& CEO. FPA then was divided into four divisions: strategic and commercial development, marine and technical services, commercial operation and executive supports. A general manager runs each of the divisions and executive support is led by a public affairs manager. Each of the divisions comprises some managers who run activities related to each division.

Under the Act 1999, FPA is also required to provide the Minister of Transport with information necessary to allow adequate assessment of the port performance each year. For example, the Annual Report for 2001 includes the following information: a report on the major operations, a review and assessment of performance against the Statement of Corporate Intended Targets, financial statements, and other information required (FPA, 2001).

\subsubsection{Key Performances Indicators (KPIs)}

Prior to the implementation of the act 1997, the KPIs of FPA only reported the effectiveness and the efficiency of the port performances in three categories: port services, port facilities and business and opportunities. Based on the new FPA's scorecard the KPIs of the firm were changed and developed. Unlike under the Port (Functions) Act 1993 where the port services and the port facilities performance indicators were reported separately, now the company is required to report the information under a new category called "port services and its KPIs". Beyond this, FPA is also obliged to report the company's market share under the trade development indicators. In 
addition, financial performance is also reported under the business improvement indicators.

Furthermore, in evaluating the port services and its facilities, FPA has also included two of types of reports: FPA Real Index and customer satisfaction reports. FPA Real Index is reports the weighted average price index deflated by the CPI for the City Perth. The average price equals the total of prices for individual FPA services weighted by their contribution to total revenue. And through the customer satisfaction reports, FPA conveys the indicators that reflect customers' satisfaction to the services and facilities provided by the port. This report consists of customer satisfactions with the FPA services and customer satisfaction with other port services. Table 2 summarizes and compares the KPIs of FPA before and after the implementation of the company corporate scorecard in 1996.

Table 2. Key performance indicators (KPIs) of FPA

\begin{tabular}{|c|c|}
\hline 1999 - Present & Pre-Act 1999 \\
\hline Services and Facilities & Port Services \\
\hline Time awaiting berth-median (hours) & Effectiveness \\
\hline Container vessels & Ship turnover \\
\hline Bulk vessels & Time at berth \\
\hline Bulk cargo processed (gross tones per hour) & Total time \\
\hline Crane rates: & Efficiency \\
\hline Container per net crane hour & Throughput \\
\hline TEUS per net crane & Cargo processed gross time \\
\hline FPA real price index & Number of containers \\
\hline Customer satisfaction with FPA services & Ship turnover \\
\hline \multicolumn{2}{|l|}{ Customer satisfaction with other ports } \\
\hline Trade Development & Port Facilities \\
\hline Total per trade (million mass tones) & Effectiveness \\
\hline Container trade & Bert occupancy \\
\hline TEUs (number) & Ship turnaround time \\
\hline Market share (\%) cargo processed (gross tones per hour) & Efficiency \\
\hline \multirow[t]{2}{*}{ Number of ship visits } & FPA costs per unit \\
\hline & FPA costs per visit \\
\hline Business Improvement & Business and Trade \\
\hline FPA profit before tax and abnormal items & Effectiveness \\
\hline Rate of return on operational assets & Total port trade \\
\hline \multirow[t]{3}{*}{ Rate of return on non-operational assets } & Total container trade \\
\hline & Efficiency \\
\hline & FPA costs per unit \\
\hline
\end{tabular}

Source: Fremantle Port Authority Business Report (1995-2002).

\subsubsection{Performances Achieved}

In the last two decade, FPA has achieved significant many progresses. The company's workforce has been reduced by almost 70 percent from 1990 to 1994 alone. In the 1993-94 Bureau of industry Economic Report on International Performance Indicators, showed that FPA had the best practice in terms of port charges for 
containers (with charges some 28 percent below the highest charging Australia port) and also the highest labor productivity for container management (FPA, 2001).

Further improvements were also achieved. As Table 3 shows, following the scorecard was implemented FPA experienced overall improvement in its operational performances. The table reveals that operational indicators - except the total port trade - have experienced improvement. Total container trade growth per annum rose from 11.4 percent during 1990/91 to 1995/96 period to 12.3 percent a year from 1995/96 to 2001/01 period. The total figures of exported and imported containers also climbed from 10.9 to 12.1 percent and from 12 to 12.5 percent at the same periods respectively (Table 3 ).

In terms of financial indicators, the company also experienced remarkable improvements. In 1996/97 the profit before income tax was \$A 10.62 million. This figure increased to just under \$A 17 million by 2000/01. Meanwhile, the Economic Rate Return also climbed from 6.9 percent in 1996/97 to around 9 percent in 2000/01. In line with the incurred pressure for better environment performance, FPA has also achieved the International Environmental Standard (ISO 14000) as the first in Australia (FPA, 2001).

Table 3.Growth per annum

\begin{tabular}{lll}
\hline Indicators & Periods & \\
& $1990 / 91-1995 / 96$ & $1995 / 96-2000 / 01$ \\
\hline Total port trade & $2.4 \%$ & $3.3 \%$ \\
Total container trade & $12.3 \%$ & $11.4 \%$ \\
Export container trade & $12.1 \%$ & $10.8 \%$ \\
Import container trade & $12.5 \%$ & $12.0 \%$ \\
\hline
\end{tabular}

Source: Fremantle Port Authority Business Report (1995-2002).

\section{Conclusions}

Previous studies have provided evidences on positive impacts of using corporate scorecard on firms' performances. However, these studies were mostly concerned with profit-seeking organizations. To generalize the evidence on a broader context, empirical studies drawn from non-for profit entities such as this one are required. Therefore, this study was aimed at investigating the impact of the adoption of a corporate scorecard system adapted from the BSC on financial and nonfinancial achievements of a public sector enterprise. The site of this study was Fremantle Port Authority (FPA), a Western Australia government-owned company. We find that the changes of the organizational structure and how it was managed was started in 1996, when the company was transformed into commercial entity. More significant changes occurred following the implementation of Act 1999. Under the new act FPA was also required to use a corporate scorecard system as a managerial tool to ensure the company's operations were in line with its mission and its strategies. Drawing from the company's experience it is clearly evidenced that FPA's strategic plan, performance measurement system have experienced improvement as expected by the ACT 1999.

It has been shown both in operational measures such as total port trade or total containers handled but also in financial terms. The company has also been awarded for its sound achievement for providing services in accordance with sound environmental practices. A main contribution of this study that expected outcomes of a new managerial innovation such as the BSC in an organization depends on the coherent link between polices and rules imposed from outside and strategies, programs and performance measurement systems implemented in accordance with the mission and goals of the organization.

Nonetheless, the results of the study cannot be generalized as a general phenomenon representing the impacts of the use of new managerial tools across state-owned enterprises in Australia. In addition, other factors such as global economic growth or regional trade development and other factors might also have affected the improvement of the FPA's performances. Therefore future research should incorporate these aspects into research models in investigating the use of corporate scorecard in a public sector context.

\section{Acknowledgements}

The authors are grateful for the helpful comments from Prof Ian RC Eggleton in the School of Accounting and Commercial Law, University of Victoria, Wellington, New Zealand on earlier versions of this paper. 


\section{References}

Adcroft, A., \& Willis, R. (2005). The (un)intended outcome of public sector performance measurement. International Journal of Public Sector Management, 18(5), 386-400.

Barry, M. A. (2000). How can performance standards enhance accountability for public health? Journal of Public Health Management Practice, 6(5), 78-84.

Braam, G. J. M., \& Nissen, E. J. (2004). Performance effects of using the Balanced Scorecard: a note on the Dutch experience. Long Range Planning, 37, 355-349.

Eggleton, I. R. C., \& Silalahi, S. (2001). Measuring the Extent of Performance Indicator Use (PIU) in the Public Sector: Preliminary Analysis. Paper presented at Flinders University Symposium on Accounting.

FPA. (2001). Statement of corporate intent. Annual Report, Freemantle, WA: FPA.

FPA [Fremantle Port Authority]. (1994-2002). Annual report, Freemantle, WA: FPA.

FPA. (2011). Annnual report. $\quad$ Retreived from http://www.fremantleports.com.au/News/Publications/AnnualReport/Reports\%202011/2011\%20Annual\%2 0Report\%201\%20-\%20full\%20report.pdf

Gadenne, D., \& Sharma, B. (2009). Balanced Scorecard Implementation in the Public Sector: Lessons Learnt in a Large Local Government Authority. Presented at AFAANZ conference. Retrieved from http://www.afaanz.org/openconf/2009/modules/request.php?module=oc_proceedings\&action=view.php\&a= Accept + as + Forum\&id $=228$

Greatbanks, R., \& Tapp, D. (2007). The impact of balanced scorecards in a public sector environment; Empirical evidence from Dunedin City Council, New Zealand. International Journal of Operations \& Production Management, 27(8), 846-873.

Gumbus, A., Bellhouse, D. E., \& Lyons, B. (2003). A three journey to organisational and financial health using the balanced scorecard: a case study at a Yale New Haven Health System Hospital. The Journal of Business and Economic Studies, 9(2), 54-64.

Harun, H., \& Kamase, H. P. (2012). Accounting Change and Institutional Capacity: The Case of a Provincial Government in Indonesia. Australasian Accounting, Business and Finance Journal, 6(2), 35-50.

Hemming, J. (2012). Balanced Scorecard-Linking Your Business Plan to Your Operational Resources and Results. http://www.unitymanagement.com.au/_blog/ideas_and_updates/tag/Small_Business/

Hoque, S., \& James, W. (2000). Linking balanced scorecard measures to size and market factors: impacts on organizational performance. Journal of Management Accounting Research, 12, 1-17.

Hurd, J. (1998). Tracking Tomorrow's Profits with Performance Measurement Systems. Mass High Tech, Jul 27-Aug 2.

Jacobs, K. (2008). Beyond commercial in confidence: accounting for power privatization in Victoria. Accounting, Auditing \& Accountability Journal, 22(8), 1258-1283.

Johanson, U., Skoog, M., Backlund, A., \& Almqvist, R. (2006). Balancing dilemmas of the balanced scorecard. Accounting, Auditing \& Accountability Journal, 19(6), 842-857.

Kaplan, R. S., \& Norton, D. P. (1996). Using the Balances Scorecard as a Strategic Management System. Harvard Business Review, January-February, 75-85.

Kaplan, R. S., \& Norton, D. P. (2002). Transforming the Balanced Scorecard from Performance Measurement to Strategic Management: Part II. Accounting Horizons, 15(2), 147-160.

Kaplan, R. S. (2001). Strategic performance measurement and management in non-profit organizations. Nonprofit Management and Leadership, 11(3), 353-370.

Lawler, E. D., Mohrman, S. A., \& Ledford, E. Jr. (1998). Strategies for High Performance Organizations: Employee Involvement, TQM and Reengineering Programs in Fortune 1000 Corporations. San Francisco, CA: Jossey-Bass.

Lawson, R., Stration, W., \& Hatch, T. (2006). Scorecarding goes global. Strategic Finance, 87(9), 34-44.

Malina, M. A., Nørreklit, H. S. O., \& Selto, F. H. (2007). Relations among measures, climate of control, and performance measurement models. Contemporary Accounting Research, 24(3), 935-982. 
Maltz, A. C., Shenhar, A. J., \& Reilly, R. R. (2003). Beyond the balanced scorecard: Refiningthe search for organisational success measures. Long Range Planning, 36(2), 187-204.

McAdam, R., Hazlett, S. A., \& Casey, C. (2005). Performance management in the UK public sector: Addressing multiple stakeholder complexity. The International Journal of Public Sector Management, 18(3), 256-273.

Menon, R., \& Tower, G. (1999). Port in Storms: What Policy Choices? Australian CPA Publication (April).

Moore, R., \& Lyon, E. M. (1995). Evaluating firm performance: why firms need to reengineer their performance measurement systems? International Journal of Bank Marketing. Retrieved from http://ecsocman.hse.ru/data/770/656/1219/firm_performance.pdf

Niven, P. R. (2002). Balanced scorecard step-by-step: maximising performance and maintaining results. New York, USA: John Wiley \& Sons.

Norreklit, H. (2003). The balanced scorecard: what is the score? A rhetorical analysis of the balanced scorecard. Accounting, Organizations and Society, 28(6), 591-619.

Northcott, D., Llewellyn, S., \& Kober, R. (2008). Testing the cause effect of the relationships in a public sector balanced scorecard. Presented at AFFAAN Conference, Sydney.

Pandey, I. M. (2005). Balanced scorecard: myth and reality. The Journal for Decision Makers, 30(1), 85-102.

Pollanen, R., \& Loiselle-Lappointe, K. (2012). Accounting Reform in the Government of Canada: Exploratory evidence on accrual accounting adoption and impact. Financial Accountability \& Management, 28(4), 59-377.

Ratnatunga, R., \& Alam, M. (2010). Strategic Governance and Management Accounting: Evidence from a Case Study. Abacus, 46(3), 343-382.

Rivers, D. L. (1999). Proactive Performance Measures. Hospital Material Management Quarterly, 20(4), 60-68.

Robinson, P. (2002). Beyond Balance Scorecard. Perth, WA: Australian CPA Publication (January).

Simons, R. (1995). Levers of Control. Boston, MA: HBS Press.

Slater, S. F., Olson, E. M., \& Reddy, V. K. (1997). Strategy-Based Performance Measurement. Business Horizons, July-August, 37-44.

Theurer, J. (1998). Seven Pitfalls to Avoid When Establishing Performance Measures in Public Management. Public Management, 80(7), 21-4.

Wisniewski, M., \& Stewart, D. (2004). Performance measurement for stakeholders: the case of Scottish local authorities. International Journal of Public Sector Management, 17(3), 222-233.

\section{Copyrights}

Copyright for this article is retained by the author(s), with first publication rights granted to the journal.

This is an open-access article distributed under the terms and conditions of the Creative Commons Attribution license (http://creativecommons.org/licenses/by/3.0/). 